\title{
PROGRAM PELAYANAN DETEKSI DINI DAN STIMULASI PERKEMBANGAN PSIKOLOGIS FASE ANAK-ANAK BAGI ORANGTUA DI KOTA DENPASAR
}

\author{
L.K.P.A. Susilawati ${ }^{1}$, I.M.Rustika ${ }^{2}$, N.K. Ekawati ${ }^{3}$, dan P.N. Widiasavitri ${ }^{4}$
}

\begin{abstract}
ABSTRAK
Orangtua memiliki peran penting pada pertumbuhan dan perkembangan masa kanak-kanak. Fase ini sangatlah penting karena menjadi dasar permulaan pengembangan semua kemampuan penting anak, baik fisik, sosial emosi, kognitif, dan perilaku. Fakta bahwa situasi hidup dan tuntutan mampu membuat orangtua tidak memiliki pilihan dalam mengasuh anak sehingga berdampak terhadap fase perkembangan di masa anak. Berdasarkan kondisi di lapangan tentang pentingnya perkembangan psikologis di masa anak-anak maka pengabdian ini ingin memberikan program pelayanan deteksi dini dan stimulasi perkembangan psikologis di fase anak-anak kepada orangtua di Kota Denpasar melalui bentuk kegiatan pemeriksaan tahap perkembangan psikologis anak usia dini yang dilanjutkan dengan penyuluhan tentang cara melakukan stimulasi di usia dini untuk mengoptimalkan tumbuh kembang anak secara psikologis. Kegiatan ini diharapkan dapat menjadi satu ketrampilan baru yang dapat bermanfaat langsung bagi orangtua di Kota Denpasar dalam melakukan pengasuhan kepada anak. Adapun kegiatan pengabdian ini menunjukkan bahwa deteksi dini dan stimulasi perkembangan dapat meningkatkan pengetahuan dan keterampilan orang tua dalam mengenali tahap perkembangan yang sesuai di usia mereka dan mendeteksi jika ada kelainan tumbuh kembang anak. Keseluruhan orang tua $(100 \%)$ sudah meunjukkan peningkatan pengetahuan setelah mengikuti kegiatan.
\end{abstract}

Kata kunci : deteksi dini, stimulasi, perkembangan psikologis, masa anak, keterampilan orangtua

\begin{abstract}
Parents have an important role in their child growth and development, especially in childhood. This phase is very important because it forms the basis of the development of all important abilities of children, whether physical, social, emotional, cognitive, and behavioral. The life situations and demands can make parents have no choice in parenting so it impacts the developmental phase of childhood. Based on the conditions about the importance of psychological development in childhood, this program wants to provide an early detection and stimulation program of psychological development in the phase of children to parents in Denpasar City through the form of early child psychological development stage examination activities followed by counseling on how to do stimulation at an early age to optimize the child's development psychologically. This activity is expected to be a new skill that can be directly beneficial for parents in Denpasar City in caring for children. The results of this program show that early detection and developmental stimulation can improve parents' knowledge and skills in recognizing appropriate developmental stages in their ages and detect if there are abnormalities of child growth. All parents (100\%) have shown improvement in knowledge after attending the event.
\end{abstract}

Keywords: early detection, stimulation, psychological development, childhood, parenting skills.

\footnotetext{
${ }^{1}$ Staf Pengajar Jurusan Psikologi Fakultas Kedokteran Universitas Udayana, pandeary@unud.ac.id ${ }^{2}$ Staf Pengajar Jurusan Psikologi Fakultas Kedokteran Universitas Udayana, imaderustika@gmail.com ${ }^{3}$ Staf Pengajar Jurusan Kesehatan Masyarakat Fakultas Kedokteran UniversitasUdayana, niko_ekapsi@yahoo.co.id ${ }^{4}$ Staf Pengajar Jurusan Psikologi Fakultas Kedokteran Universitas Udayana, putunugrahaeni.w@gmail.com
} 


\section{PENDAHULUAN}

Masa anak-anak tidak terlepas dari fase pertumbuhan dan perkembangan. Pertumbuhan berkaitan dengan masalah perubahan dalam besar, jumlah, ukuran atau dimensi tingkat sel, organ, maupun individu. Perkembangan lebih menitikberatkan pada aspek perubahan bentuk atau fungsi pematangan organ tubuh individu, termasuk perubahan aspek sosial atau emosional akibat pengaruh lingkungan (Markum, 1996).

Proses pertumbuhan dan perkembangan yang optimal tidak hanya didasari oleh aspek-aspek pertumbuhan, tapi harus memperhatikan juga aspek perkembangan psikologis seperti perkembangan motorik, komunikasi, emosi, sosial, dan tingkah laku. Pemantauan terhadap aspek perkembangan psikologis belum menjadi perhatian di masyarakat umum, artinya proses perkembangan anak akan berjalan sesuai usianya dan kalaupun ada keterlambatan perkembangan masih dipandang sebagai hal biasa. Padahal aspek-aspek perkembangan psikologis juga sama pentingnya dengan aspek pertumbuhan pada seorang anak. Masa kanak-kanak merupakan masa pengenalan dasar pertama kali dalam mengembangkan kemampuan fisik, sosial emosi, kognitif, dan moral sehingga perkembangan yang optimal sejak dini di masa ini akan memberikan kemampuan-kemampuan yang adaptif di fase perkembangan berikutnya (Herlina, 2013).

Orangtua masih belum memahami bahwa gangguan atau penyimpangan pada masa perkembangan anak bisa dideteksi secara dini untuk meminimalkan dampak negatif yang luas dari kondisi tersebut. Keadaan ini tentu dipengaruhi oleh tingkat pendidikan dan pengetahuan orangtua sehingga perlu diupayakan suatu program pelayanan yang mampu memberikan pengetahuan dan pemahaman kepada masyarakat bahwa deteksi secara dini dan penangangan lebih lanjut melalui stimulasi penting diketahui oleh semua orangtua yang masih memiliki anak-anak usia dini.

Kondisi kota Denpasar yang menjadi daerah tujuan urban sehingga banyak terdapat penduduk pendatang, selain penduduk asli. Tuntutan kebutuhan hidup yang tinggi membuat orangtua harus bekerja atau mempekerjakan pengasuh sehingga perkembangan anak menjadi kurang diperhatikan dengan seksama. Orang tua baru menyadari anaknya mengalami keterlambatan atau gangguan dalam perkembangan setelah timbul masalah dan melakukan pemeriksaan ke dokter atau psikolog. Berdasarkan kondisi tersebut, kegiatan pengabdian ini dilakukan untuk memberikan pelayanan kesehatan psikologis dalam bentuk deteksi dini dan stimulasi perkembangan psikologis fase anakanak dengan mengajak orangtua untuk lebih peka memperhatikan aspek-aspek perkembangan psikologis anak agar jika ditemukan keterlambatan perkembangan dapat diupayakan penanganan sedini mungkin. Selain itu, agar anak dapat terus bertumbuh dan berkembang sesuai dengan tahapan usianya dengan stimulasi yang optimal.

\section{METODE PELAKSANAAN}

Untuk dapat menjawab permasalahan tentang pelayanan deteksi dini dan stimulasi perkembangan psikologis fase anak-anak bagi orangtua di kota Denpasar dalam melakukan pengasuhan yang optimal kepada anak, maka strategi pemecahan masalah yang diupayakan antara lain:

a. Menyusun check-list tahap perkembangan psikologis anak di usia dini yang akan digunakan oleh orangtua untuk melakukan deteksi dini dengan didampingi oleh Psikolog.

b. Melakukan pemeriksaan deteksi dini dengan mengajak orangtua menggunakan check-list. Tujuan orangtua dilibatkan dalam melakukan pemeriksaan agar orangtua peka dengan perkembangan anak mereka dan memiliki kemauan dan ketrampilan untuk melakukang antisipasi melalui stimulasi.

\section{2 | BULETIN UDAYANA MENGABDI}


c. Selanjutnya dilakukan penyuluhan tentang stimulasi perkembangan psikologis masa anak kepada orangtua setelah mereka melakukan pemeriksaan melalui check-list untuk memberi pemahaman dan ketrampilan dalam melakukan stimulasi.

d. Pada akhir kegiatan, dilakukan sesi tanya jawab untuk memfasilitasi kebutuhan dan pertanyaan dari orangtua atas proses yang sudah mereka lakukan dalam kegiatan ini.

\section{HASIL DAN PEMBAHASAN}

Hasil yang dipaparkan dalam kegiatan pengabdian ini adalah deteksi tahapan perkembangan psikologis anak dengan menggunakan check-list, dan diakhiri dengan pertanyaan-pertanyaan dalam sesi tanya jawab dari orang tua.

Tabel 3.1. Check-list Deteksi Tahap Perkembangan Usia 2-3 Tahun

\begin{tabular}{|c|l|c|c|c|}
\hline \multirow{2}{*}{ No } & \multicolumn{2}{|c|}{ Aspek Perkembangan } & \multicolumn{3}{c|}{ Tingkat Perkembangan } \\
\cline { 3 - 5 } & & Kurang & Cukup & Baik \\
\hline 1 & Perkembangan Moral dan Nilai Agama & - & 3 & - \\
\hline 2 & Perkembangan Sosial dan Emosional & - & - & 3 \\
\hline 3 & Perkembangan Bahasa & - & 1 & 2 \\
\hline 4 & Perkembangan Kognitif & - & 2 & 1 \\
\hline 5 & Perkembangan Fisik/Motorik & - & - & 3 \\
\hline
\end{tabular}

Hasil pada tabel 3.1. menunjukkan bahwa sebagian besar tahapan perkembangan anak-anak usia 2 - 3 tahun tergolong cukup dan sudah memenuhi standar pada tahap perkembangan usia mereka.

Tabel 3.2. Check-list Deteksi Tahap Perkembangan Usia 3-4 Tahun

\begin{tabular}{|c|l|c|c|c|}
\hline No & \multicolumn{2}{|c|}{ Aspek Perkembangan } & \multicolumn{3}{|c|}{ Tingkat Perkembangan } \\
\cline { 3 - 5 } & & Kurang & Cukup & Baik \\
\hline 1 & Perkembangan Moral dan Nilai Agama & - & 6 & - \\
\hline 2 & Perkembangan Sosial dan Emosional & - & 3 & 3 \\
\hline 3 & Perkembangan Bahasa & 1 & 2 & 3 \\
\hline 4 & Perkembangan Kognitif & - & 2 & 4 \\
\hline 5 & Perkembangan Fisik/Motorik & - & - & 6 \\
\hline
\end{tabular}

Hasil pada tabel 3.2. menunjukkan bahwa hampir keseluruhan tahapan perkembangan anak-anak usia 3 - 4 tahun tergolong cukup dan sudah memenuhi standar pada tahap perkembangan usia mereka. Namun ada 1 anak yang tahap perkembangan bahasanya memerlukan stimulasi lebih lanjut.

Tabel 3.3. Check-list Deteksi Tahap Perkembangan Usia 4-5 Tahun

\begin{tabular}{|c|l|c|c|c|}
\hline No & \multicolumn{1}{|c|}{ Aspek Perkembangan } & \multicolumn{3}{|c|}{ Tingkat Perkembangan } \\
\cline { 3 - 5 } & & Kurang & Cukup & Baik \\
\hline 1 & Perkembangan Moral dan Nilai Agama & - & 2 & 49 \\
\hline 2 & Perkembangan Sosial dan Emosional & - & 10 & 41 \\
\hline 3 & Perkembangan Bahasa & 2 & 11 & 38 \\
\hline 4 & Perkembangan Kognitif & - & 12 & 39 \\
\hline 5 & Perkembangan Fisik/Motorik & 1 & 10 & 40 \\
\hline
\end{tabular}

Hasil pada tabel 3.3. menunjukkan bahwa hampir keseluruhan tahapan perkembangan anak-anak usia 4 - 5 tahun tergolong cukup dan sudah memenuhi standar pada tahap perkembangan usia mereka. Namun ada 2 anak yang tahap perkembangan bahasa dan 1 anak yang tahap perkembangan fisik/motoriknya memerlukan stimulasi lebih lanjut. 
Tahapan kegiatan kedua adalah penyuluhan tentang stimulasi perkembangan psikologis masa anak kepada orangtua dengan pemberian materi dan handout. Orang tua diberikan informasi tentang perkembangan anak mereka pada setiap tahapan dan diajak untuk mengenali, mengobservasi perkembangan anak secara intensif. Jika ditemukan adanya keterlambatan perkembangan atau tidak sesuai dengan tuntutan perkembangan pada usia tersebut, maka orang tua diberi beberapa alternatif solusi yang bisa dilakukan. Seperti melakukan konsultasi kepada profesional tentang tumbuh kembang anak, mengikuti seminar tentang anak, maupun forum parenting.

Tahap terakhir kegiatan adalah tanya jawab berdasarkan hasil deteksi yang sudah dilakukan orang tua maupun tahap perkembangan yang lain yang ingin diketahui. Beberapa pertanyaan orang tua seputar perkembangan bahasa anak dan perkembangan motorik. Hasil check-list juga menunjukkan sebagian kecil orang tua memiliki anak dengan tahap perkembangan yang lambat pada aspek bahasa dan motorik.

Hasil di atas menunjukkan bahwa deteksi dini dan stimulasi perkembangan dapat meningkatkan pengetahuan dan keterampilan orang tua dalam mengenali tahap perkembangan yang sesuai di usia mereka dan mendeteksi jika ada kelainan tumbuh kembang anak. Keseluruhan orang tua (100\%) sudah meunjukkan peningkatan pengetahuan setelah mengikuti kegiatan.

Tabel 3.4. Hasil Evaluasi deteksi dini dan stimulasi perkembangan psikologis masa anak-anak

\begin{tabular}{|c|l|c|c|}
\hline No & \multicolumn{1}{|c|}{ Katagori Nilai } & Jumlah peserta & Persentase \\
\hline 1 & $\begin{array}{l}\text { Ada peningkatan pengetahuan dan } \\
\text { ketrampilan melakukan deteksi dini. }\end{array}$ & 65 & $100 \%$ \\
\hline 2 & $\begin{array}{l}\text { Tidak ada peningkatan pengetahuan } \\
\text { dan ketrampilan melakukan deteksi } \\
\text { dini. }\end{array}$ & 0 & $0 \%$ \\
\hline \multicolumn{2}{|l}{ Jumlah } & 65 & $100 \%$ \\
\hline
\end{tabular}

Berdasarkan proses selama kegiatan pengabdian, orang tua telah memiliki pengetahuan, pemahaman serta ketrampilan untuk melakukan pemantauan terhadap perkembangan anak mereka. Kegiatan pengabdian masyarakat ini diharapkan sedikit demi sedikit dan perlahan mampu menjangkau orang tua lainnya yang memiliki anak usia dini dan meningkatkan meningkatkan kemampuan anak pada setiap usia perkembangannya.

\section{KESIMPULAN DAN SARAN}

\subsection{Simpulan}

Kegiatan pengabdian pada masyarakat diberikan melalui penyuluhan tentang stimulasi perkembangan psikologis masa anak diberikan melalui materi dan handout. Orang tua diberikan informasi tentang perkembangan anak mereka pada setiap tahapan dan diajak untuk mengenali, mengobservasi perkembangan anak secara intensif. Kegiatan akhir adalah tanya jawab, berdasarkan hasil deteksi yang sudah dilakukan orang tua maupun tahap perkembangan yang lain yang ingin diketahui. Adapun kegiatan pengabdian ini menunjukkan bahwa deteksi dini dan stimulasi perkembangan dapat meningkatkan pengetahuan dan keterampilan orang tua dalam mengenali tahap perkembangan yang sesuai di usia mereka dan mendeteksi jika ada kelainan tumbuh kembang anak. Keseluruhan orang tua $(100 \%)$ sudah meunjukkan peningkatan pengetahuan setelah mengikuti kegiatan. Kegiatan pengabdian masyarakat ini diharapkan sedikit demi sedikit dan perlahan mampu menjangkau orang tua lainnya yang memiliki anak usia dini dan meningkatkan meningkatkan kemampuan anak pada setiap usia perkembangannya.

\section{4 | BULETIN UDAYANA MENGABDI}




\subsection{Saran}

Berdasarkan peran orangtua dalam mendeteksi pertumbuhan dan perkembangan anak usia dini, maka penting bagi orangtua untuk memiliki pengetahuan dan ketrampilan tentang tahapan perkembangan psikologis anak, bagaimana mendeteksi perkembangan dan pertumbuhan anak usia dini, serta langkah apa yang dapat dilakukan oleh orangtua untuk mengoptimalkan pertumbuhan dan perkembangan anak usia dini. Kegiatan pengabdian ini diharapkan mampu memberikan wawasan dan ketrampilan sehingga dapat diterapkan sehari-hari oleh orangtua.

\section{UCAPAN TERIMAKASIH}

Penulis mengucapkan terima kasih kepada Litbang Fakultas Kedokteran Universitas Udayana yang telah memberikan dukungan dana sehingga pelaksanaan kegiatan ini dapat berjalan sesuai rencana. Ucapan terima kasih pula kepada para orangtua siswa PAUD di Kota Denpasar yang telah berpartisipasi dalam kegiatan ini, serta kepada semua pihak yang telah mendukung kegiatan ini.

\section{DAFTAR PUSTAKA}

Herlina. (2008). Deteksi Dini Dalam Perkembangan. Bandung: Jurusan Psikologi FIP UPI. Diktat Kuliah (Tidak Diterbitkan).

Markum, A.H. (1996). Ilmu Kesehatan Anak. Jakarta : Fakultas Kedokeran Universitas Indonesia. 